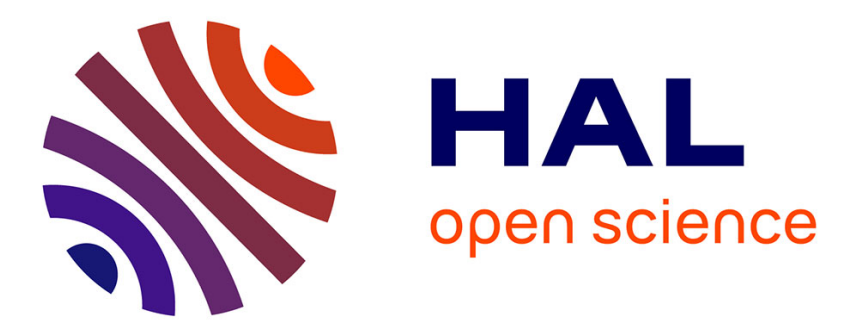

\title{
Importance of Bidimensional Data Matrix Code Against Medicine Counterfeiting
}

\author{
André De Lira Muniz, Marcelo Nogueira, Jair Minoro Abe
}

\section{To cite this version:}

André De Lira Muniz, Marcelo Nogueira, Jair Minoro Abe. Importance of Bidimensional Data Matrix Code Against Medicine Counterfeiting. IFIP International Conference on Advances in Production Management Systems (APMS), Sep 2015, Tokyo, Japan. pp.582-588, 10.1007/978-3-319-22756-6_71 . hal-01417616

\section{HAL Id: hal-01417616 https://hal.science/hal-01417616}

Submitted on 15 Dec 2016

HAL is a multi-disciplinary open access archive for the deposit and dissemination of scientific research documents, whether they are published or not. The documents may come from teaching and research institutions in France or abroad, or from public or private research centers.
L'archive ouverte pluridisciplinaire HAL, est destinée au dépôt et à la diffusion de documents scientifiques de niveau recherche, publiés ou non, émanant des établissements d'enseignement et de recherche français ou étrangers, des laboratoires publics ou privés. 


\title{
Importance of bidimensional Data Matrix code against medicine counterfeiting
}

\author{
André Gomes de Lira Muniz ${ }^{1}$, Marcelo Nogueira ${ }^{1,}$ Jair Minoro Abe ${ }^{1 .}$ \\ ${ }^{1}$ Graduate Program in Production Engineering in Software Engineering Research Group at \\ UNIP, University Paulista, São Paulo, Brazil \\ \{a.gdelira@gmail.com, marcelo@noginfo.com.br, \\ jairabe@uol.com.br\}
}

\begin{abstract}
In the recent years the world has faced significant problems related to public health and the counterfeiting of medicines, which has become a critical factor for the world population. It was verified that studies on this scope are few and the concern is due to the fact that It represents many losses, reaching the value of 8 millions reais with counterfeit medicines in 2013 and lack of traceability. This study aims to present a national and global screen view of tracing systems using the bidimensional code Data Matrix by showing its importance and use in hospitals. It is an applied research with qualitative and descriptive approach, relying on bibliometric study on databases such as ScienceDirect, Portal Capes and Ebsco on the period comprehended between 2004 and 2014 and using the keywords traceability, drugs, health care and Data Matrix. The results show that the theme is not well explored on the scientific community, achieving ten papers on the previously mentioned databases. It is considered an important subject concerning to financial health on a company.
\end{abstract}

Keywords: Traceability, medicine, Data Matrix

\section{$1 \quad$ Introduction}

The pharmaceutical industry was held responsible for problems arising from the use of medicines in the use chain [1]. However, the current situation and advances in tracking, reverse logistics, interchangeability of specific drugs and regulations have provided a meaningful way to address this issue. Currently beyond the financial aspect, consumer safety became mandatory from the perspective of responsibility and business ethics.

Prioritize the safety and quality of products and services contributes decisively to customer loyalty, and strengthening the relation-ship between patient and health institutions. This situation is critical and patient safety in hospitals is a matter to be analyzed in depth in society [1]. Every year, thousands of people suffering from medical errors caused by flaws in the administration of medication and hospital procedures. A adfa, p. 1, 2011.

(c) Springer-Verlag Berlin Heidelberg 2011 
set of "best practices" has been developed and implemented by organizations that demonstrate an awareness in management processes, activities and relationship with patients. The challenge of improving its internal processes, based on continuous improvement with the technological support and new working methods. Traceability shall then be a way for industry and health organizations to implement management systems, providing efficiency in its operations, customer value and to remain competitive in the market.

Before the proposed objective, opposite the importance of the topic and its application, analyze the traceability of pharmaceutical drugs operating in Brazil, conducting applied research, given that it is not pure science; quantitative because they are used figures on counterfeit drugs in Brazil; and descriptive, for he knows the main object of study. Supported by pillars of traceability, which is the ability to track bidirectional forward with application or location of the same [2], evaluation of historical medications, with their resilience through recorded identifications, allowing the tracking of what is considered as sources of consultations.

\section{$2 \quad$ A bias of the problem}

In recent years the world is faced with significant problems related to public health and counterfeit drugs has become a critical factor for the world's population. The drug falsification of its holistic approach can vary according to country [3]. May classify drug counterfeiting the form of manufacturing the pharmaceutical product by someone not authorized to do so by copying or imitating the original without permission and with the purpose of deception or fraud by selling the product as if it were the original.

Aiming to solve the problem of definition of counterfeit medicines, the World Health Organization - WHO established a definition: "Counterfeit medicine is one which is deliberately and fraudulently subject to a change of identity and/or source. In conclusion that the product can be or generic brand and may include products with the correct or incorrect composition without active components, with insufficient active components or with a packaging false" [4]. In Brazil, according to Law No. 8,072/90, counterfeiting is a heinous crime, prompting the offender to be penalized without the traditional mercies as bail, pardon and others, that despite the rigidity of the sentence, in an attempt to inhibit such crimes, not extinguish the problem. The society, government and industry must find solutions that restrain counterfeiting with effective mechanisms for control of production and distribution of medicines.

Faced with this challenge, the private sector, society and government leaders around the world have sought effective ways to combat counterfeiting. We know that, to a 
greater or lesser degree of difficulty, the current mechanisms in the package can still be played and lead the consumer to a misunderstanding that can be fatal.

\subsection{Global Trends}

The creation of the World Health Organization, a specialized agency for health in 1948 developed of norms, standards and processes in search of a suitable level of health for all people. WHO aims the quality of drugs at the international level and that makes recommendations to combat and prevent counterfeit drugs requiring not only cooperation between institutions but also at international level.

With the rise of international trade in drugs and ease in Internet sales was the rapid expansion of the counterfeit goods trade. With that in 2006 WHO held an international task force to combat Counterfeit pharmaceuticals (IMPACT), composed by Interpol Intellectual Property Organization, and the agencies and associations of countries that seeks to share knowledge to identify problems, seek solutions and coordinate activities.

In Brazil, the creation of ANVISA in 1999 began regulating the supervisory process in the country, it is one set up a body with special authority to direct and independent public administration.

The first fake ID case in Brazil was registered in 1877. In 1991, was identified nine brands of tetracycline antibiotics were forged eleven that existed in the market.

The drug counterfeiting practices worsened between 1997 and 1998 being registered 172 cases of forgery by the Ministry of Health. Appeared counterfeit medicines for the treatment of prostate cancer, for example Androcur Schering of Brazil, led to worsening of the disease and died at least five patients who used the fake medicines.

Competition in the Brazilian drug market is being fought not only by national and foreign companies, there's a new competitor that is in pursuit of revenue from this market in 2013 had revenues of 3 trillion [5]. According appointment of the National Anti-Piracy Forum - FNCP, suppliers of smuggled, counterfeit and pirated products have a turnover of 30 billion dollars in the last year (2013). Counterfeiting and smuggling of products generate damage amounting to eight billion dollars a year representing $20 \%$ of the total market and about five billion dollars of tax evasion and in Brazil,it is considered a heinous crime, this number doubles the world average of $10 \%$, as shown by WHO studies [5].

The IRS conducted the seizure of more than 40 million dollars in smuggled medicines since 2010, and at first the door of counterfeit products in Brazil is Paraguay which 
accounts for 20 billion two-thirds of ticket dollars per year in illegal products. Traceability of medicines in the production chain aims at prevention and drug misuse weakening and reducing counterfeit products, enabling the identification of lots with quality problems or of dubious origin and quickly re-moving market.

\section{Tracing - Using the automating tool for medicine safety}

With technological advances and influences imposed by contemporary society has required adoption of increasingly bold solutions requiring restructuring of the productive sectors based on efficiency, so having an effective production ceased to be a differential and became a synonym for survival in the corporate panorama. The veracity in the economy and consumer market demand establish crucial factors in the survival of an enterprise, synonyms such as price, quality, innovation, term commitment to the safety of people and the environment are not evident guarantees attesting product quality [6]. The ability to enter detailed information about the origin and characteristics of the products distributed, according to batches or individually, at various stages of the production chain, has become an important instrument of commercial advantage. In addition to representing a key condition to meet the demands of consumers.

Law 11,903 , of January 14,2009 , deals with the traceability of production and consumption of drugs [7]. Ratifies the law 12097 of 24 November 2009, where debate the concept and application of traceability in the supply chain of bovine meat and buffalo. Finally, the law 12.305, of August 2, 2010, establishing the national solid waste policy [6]. This set of law refers traceability in Brazil to a new level, transferring to businesses, industries, businesses, insurance companies, hospitals and others the responsibility of collecting products put on the market. On international standards ISO 9000 is the following definition, traceability is defined as the ability to trace the history, applications or the location of products from its origin to the consumer [8]. The hospital side, traceability is the hospital's ability to control the receipt, distribution, dispensing and administration of batch and validity of drug processes [6]. To set, traceability in this study was used to Occam's razor, so traceability is defined as the origin of the product identification from the raw materials used, production process, market distribution to consumption [9]. As a result of tampering and counterfeit drugs is notorious the need to establish a process to control the product distribution chain to the end consumer, the process control should identify the lot and the validity and be registered so that they can monitor the stages of the entire cycle in jail where he is. In hospital approach, lack of process control directly affects the hospital control and that the hospitals studied alternatives to address this lack of information and to control properly the information concerning the product, new technologies for identification and product traceability comes in market, including the two-dimensional code. 


\subsection{The risks of palliative solutions and innovation}

The work of relabeling is a stopgap solution and can bring some risks to update data because the control process has a heavy reliance on human interaction and a methodology that guarantees some checkpoints and data validation during the information chain. And for this control to be effective it is necessary to invest in labor-work which increases the cost of operation. There is also the entrance possibility in the stock of medicine with error in the hospital and, therefore, is essential to control of lots and the internal redistribution of products by updating controls and information systems.

One possible risk is duplication of information and the potential damage and to corrupt the traceability of medicines during the time he is active in the system. Therefore, validate the quality of labels, printing program, as well as keeping the maintenance of printers, and have adequate quality control process promotes sustainable solution.

According to a study from the Institute of Medicine (2001) shows that even in first world countries, such as in the United States at a rate of $24 \%$ utilization in reading bar codes in hospitals to make the conference of the product before being effective dispensing and to control inventory $29.9 \%$ using this technology. Therefore proper identification in the pharmaceutical industry is relevant [10]. The creation of the twodimensional code that has a variable format may promote the information that hospitals need and thus meet the need of retagging and yet increase the quality assurance in medicine. While reading the new code, automatic batch data import and validity restrict the occurrence of error for the inclusion of data in the system and thus expand the inventory management assurance company. Based on studies conducted on the status of the hospital pharmacy by the American Society of Health-System Pharmacists (ASHP) highlights the cost reduction and expansion of security, mobilizing the fitness industry and the supply of drugs in individual doses and identified with bar codes, as identified in the study group of GS1 Brazil. This requires adapting the packaging and the code for single doses. This will be possible because, you can register up to 55 characters in a print only 2-3 mm2. Importantly, the GS1 Data Matrix code is being used in various medicines and ease of reduced printing and of great importance to the unit or small doses consumption.

\subsection{Application in the medical field}

In January 2009 it was published the Law 11,903, which creates the National System of Drug Control, which must be done through identification system, with the use of the capture, storage and electronic data transmission technologies. Companies will have a gradual period of three years for the implementation of the Data Matrix system. This law will bring numerous benefits to the industry, such as better control and 
security in the fight against counterfeiting, smuggling and theft; traceability of products by automated records systems.

Data Matrix is a worldwide used model that allows the identification of various features and product information through encryption that guarantees the traceability of the products from the beginning of the production process to end use. The data matrix was chosen for use in medicine because it has the ability to in-stall in smaller sized packages, such as medical and surgical equipment. Some companies are already deploying the system. Pharmaceutical industries as Eurofarma concluded its implementation in 2009; Baxter, who in March 2009 put its entire line with new print system; some hospitals in São Paulo as the German Hospital Oswaldo Cruz and the Hospital Israelita Albert Einstein also already part of users of the Data Matrix code.

\subsection{Benefits of using the Data Matrix in the hospital area:}

As well as the industries of medicines, which are currently required to use the Data Matrix code is believed that this logo will also be an obligation to suppliers of hospital products in this way, companies in this sector, are already anticipating and so making use this code in marketing your products has the following benefits

Alignment with the industry, given the mandatory implementation; Ease of traceability of products and medicines; Process improvement; Precise handling of inventories reflecting an improvement in purchasing management; Cost savings because there is no more need to use labels and ribbons; Of waste volume reduction is also a gain, because there is no longer a need to issue labels that future would be discarded.

All work in health aims to patient safety. An efficient traceability system is an-other component for ensuring the safety through the safe use of medicines and hospital medical supplies.

Noted that CT - Surgical Technique Trade Hospital Materials LTDA, importer of hospital supplies in 2011 invested in this technology and thus provided its customers yet another benefit [11]. Finally the author connotes that some of the customers already using Data Matrix in the use of medications such as German Hospital Oswaldo Cruz and the Hospital Israelita Albert Einstein mentioned above.

\section{$4 \quad$ Materials and Methods}

The present work, with quantitative essence, has descriptive and bibliographical character. To proceed the investigation, a bibliometric study was performed. According to [12], a bibliometric research consists on applying statistical techniques and mathematical patterns to descript aspects from literature and other means of communication. 
Initially, scientific papers were selected for data collecting related to tracing using Data Matrix on medicines of health services. Choosing the papers was due to their representativeness on scientific research on academic scope. A time gap is 10 years was considered, between 2004 and 2014. The papers were collected from a research containing the following keywords: traceability, datamatrix, health care and drugs. The sampling resulted in ten papers from the following sources: Science Direct, Portal Capes and Ebsco. After selection, a database was created to perform the bibliometric analysis with origin, author, title and correlated keywords for each paper, as follows:

\begin{tabular}{|c|c|c|c|c|c|c|}
\hline Origem & Autor & \begin{tabular}{|c|} 
Titulo \\
\end{tabular} & Drugs & Traceability & DataMartrix & HealthCare \\
\hline \multirow{7}{*}{ Science Direct } & R. Ducommuna, S. Gloora, P. Bonnabry & $\begin{array}{l}\text { Risk of errors related to deficiencies in the } \\
\text { identification of drug unit doses }\end{array}$ & $\mathrm{x}$ & $\mathrm{x}$ & & $\mathrm{x}$ \\
\hline & F.J. Lagrange and F. Jacq & $\begin{array}{l}\text { Developing an innovative oral unit dose robot } \\
\text { dispenser: Patient care performance and industrial } \\
\text { perspectives }\end{array}$ & $\mathrm{x}$ & & & $\mathrm{x}$ \\
\hline & $\begin{array}{l}\text { Luca Mainetti and Luigi Patrono and Maria Laura } \\
\text { Stefanizzi and Roberto Vergallo }\end{array}$ & $\begin{array}{l}\text { An innovative and low-cost gapless traceability } \\
\text { system of fresh vegetable products using RF } \\
\text { technologies and EPCglobal standard }\end{array}$ & & & & \\
\hline & $\begin{array}{l}\text { Ahmed Musa and Angappa Gunasekaran and } \\
\text { Yahaya Yusuf }\end{array}$ & $\begin{array}{l}\text { Supply chain product visibility: Methods, systems } \\
\text { and impacts }\end{array}$ & & $\mathrm{x}$ & & \\
\hline & J. Plimmer & $\begin{array}{l}\text { Trends in Packaging of Food, Beverages and Other } \\
\text { Fast-Moving Consumer Goods (FMCG) }\end{array}$ & & $\mathrm{x}$ & & \\
\hline & $\begin{array}{l}\text { E. Raingeard, J.-C. Fréville, G. Grimandi, A. } \\
\text { Truchaud }\end{array}$ & $\begin{array}{l}\text { Intérêt de l'automatisation de la distribution du } \\
\text { médicament - méthode de comparaison des } \\
\text { technologies disponibles sur le marché français }\end{array}$ & & $\mathrm{x}$ & & $\mathrm{x}$ \\
\hline & George Roussos & $\begin{array}{l}\text { Computing with RFID: Drivers, Technology and } \\
\text { Implications }\end{array}$ & & $\mathrm{x}$ & & \\
\hline \multirow{3}{*}{ Ebsco } & Dennison, Avery & France is first to to set the code. & $\mathrm{x}$ & $\mathrm{x}$ & $\mathrm{x}$ & \\
\hline & Stobie, Craig & On the right track. & & & & \\
\hline & Plain-Jones, Charlie & When Simple isn't Good Enough. & $\mathrm{x}$ & $\mathrm{x}$ & $\mathrm{x}$ & $\mathrm{x}$ \\
\hline
\end{tabular}

Figure 1. Bibliometric study of keywords (source, authors).

It is noteworthy that not part of the object of this study, the other processes involved, nor other specific variables for mining of the above mentioned data, ie presenting a structure chain of medical supplies, as this would be an extension of this outbreak, which I would refer to other types of studies that were not in the midst of the objectives

\section{$5 \quad$ Final Considerations}

Performing this study enabled a better understanding about the work and importance of Data Matrix Bidimensional code. It was noticed that scientific literature does not explore this subject as it should, as management mistakes may cause high organizational impacts, leading the company to financial, ethical and moral losses. A significant rise on companies from diverse sectors that have adopted Data Matrix for identification of their products, particularly the pharmaceutical industry, as its use is mandatory due to law 11.903 that creates National System of Medicine Control. 
For several times the responsible for hospital pharmacies have found obstacles which restrain the development of tracing projects and it is not uncommon that the reason is lack of support or financial resources. However, it is worth noting that there are solutions that adapt to a wide variety of budgets, as it has been exposed.

It is also worth noting that, facing the costs generated by error and time spent with workforce do not add value and offer more risks. They are factors that may show the quick feedback of the investment.

In addition, the focal point is the attention to regulations. With this study, it is expected the health assistance reaches a higher quality level, when it comes to authentic products and legal origin, as well as expect that a regulation for primary packages based on GS1 Data Matrix is created.

\section{Acknowledgements}

This work has been supported by FCT - Fundação para a Ciência e Tecnologia in the scope of the project: PEst-OE/EEI/UI0319/2014 by Portugal and University Paulista Software Engineering Research Group by Brazil.

\section{$7 \quad$ References}

1. Camargo, F., 2006. Rastreabilidade: sinônimo de eficiência e segurança, s.l.: s.n.

2. Mello, C. H. P., da Silva, C. E. S., Turrioni, J. B. \& de Souza, L. G. M., 2002. ISO 9001: 2000: Sistema de Gestão da Qualidade para Operações de Produção e Serviços. s.l.:Atlas.

3. Virella, D., 2008. Falsificação de medicamentos. Uma realidade à qual é preciso dar atenção. Acta Pediátrica Portuguesa, 39(1), pp. 46-50.

4. WHO, W. H. O. \& others, 2007. General information on counterfeit medicines, s.l.: s.n.

5. CFF, C. F. d. F., 2014. O mercado negro de medicamentos, s.l.: s.n.

6. Rocha, R. U. G. D., 2012. Fluxo da informação no sistema de rastreabilidade em uma empresa do segmento eletrônico, Curitiba: s.n.

7. Nogueira, E. \& Neto, G. V., 2011. COUNTERFEIT DRUGS AND LAW N. 11.903/09: LEGAL ASPECTS AND IMPACTS. Revista de Direito Sanitário, Jul./Out, 12(2).

8. Santos, A. R. D., 2014. Rastreabilidade "do laboratório à mesa" : um estudo da cadeia produtiva da indústria de carne suína na empresa Doux, Caxias do Sul: s.n.

9. Malta, N. G., 2014. Farmácia Hospitalar Rastreabilidade de medicamentos na farmácia hospitalar, s.l.: s.n.

10. Kreysa U, Denecker J. Enabling safer patient care automatic identification standards for phar-maceutical and medical devices. International hospital federation reference book 2007/2008.p.32-35.

11. Souza, D. L. D., Souza, G. D., Bregenski, L. A. \& Fraiz, S., 2010. DATA MATRIX, CURITIBA: s.n.

12. Araújo, C. A. Bibliometria: Evolução história e questões atuais. Em questão, Porto Alegre, v. 12, n. 1, p. 11-32, jan./jun. 2006. 